4. Свалова Е. В. Особенности обучения иностранному языку учащихся младших классов средней общеобразовательной школы// Педагогическое образование в России. 2014. №6. C.159-162.

\title{
Индивидуализация в малокомплектной школе на уроках физической культуры
}

\author{
Крылов С.А., учитель физической культуры, \\ Хара-Алданская средняя общеобразовательная школа, \\ Таттинский район, с. Хара-Алдан \\ E-mail: oxstarost@mail.ru
}

Исследование посвящено изучению индивидуализации в малокомплектной школе на уроках физической культуры. Физическая культура и спорт являются важным составляющим в жизни каждого человека. Тем более, в нашем современном мире, когда большинство детей в свободное время предпочтут поиграть в планшеты, телефоны, компьютеры, чем пойдут в спортзал.

Индивидуализацию обучения объясняет автор термина В.А. Крутецкий как «ориентация на индивидуально-психологические особенности ученика, выбор и применение соответствующих методов и приемов, различные варианты задания, дозировка домашних заданий» [2].

В педагогическом словаре дается определение индивидуализации обучения как «организация учебного процесса с учетом индивидуальных особенностей учащихся; позволяет создать оптимальные условия для реализации потенциальных возможностей каждого ученика. Индивидуализация обучения осуществляется в условиях коллективной учебной работы в рамках общих задач и содержания обучения» [1, стр. 46]

Напротив, А.А. Кирсанов утверждает, что индивидуализация обучения это широкое понятие процесса обучения. Сюда входят деятельность учителя, деятельность ученика и весь процесс обучения и подготовки.

Далее рассмотрим варианты индивидуализации, которых объединил И.Э. Унт в условные группы:

1) дифференциация обучения, то есть группировка учащихся на основе их отдельных особенностей или комплексов этих особенностей для обучения по нескольким различным учебным планам или программам. Так создаются относительно гомогенные группы (классы, школы);

2) внутриклассная (внутригрупповая) индивидуализация учебной работы (фронтальная, групповая и индивидуальная формы классной работы);

3) прохождение учебного курса в индивидуально различном темпе: или убыстренно (акселерация), или замедленно (ретардация) [3].

Итак, практическая часть исследования предусматривает индивидуализацию обучения в малокомплектной школе во время уроков физической культуры. В связи с глобальной урбанизацией, в сельских школах с каждым годом все меньше детей, молодые родители стремятся переехать в город. Исходя из этого в селах очень много малокомплектных школ. А в малокомплектной школе наряду с этой проблемой, мы сталкиваемся еще с ненаполняемостью классов. В каждом классе по 4-5-6 детей. 
Поэтому применяются эффективные средства организации педагогического процесса (различные варианты упражнений и заданий соответствующие методы и приемы).

Однако малая наполняемость класса дает и положительные результаты:

1) Осуществляется индивидуальный подход к ученикам с учетом интереса и уровня;

2) Личное общение с учениками;

3) Практическая направленность;

4) Прочное усвоение знаний и умений.

На уроках физической культуры объединяем в комплекты 2 класса, иногда 3. Например, 9,10,11 классы в 1 комплект, или 8-9 классы и 10-11. При объединении классов учитывается количественный состав, близость возраста, сложность программы и подготовленность. Формируется общая компетенция - работа в команде. Крайне сложно провести игры, где нужны 2 команды из 6 человек. Например: волейбол, баскетбол, футбол, пионербол и др. Но во время внеучебной деятельности (занятий, кружков) можно провести такие игры, где выходит полная команда. Вместо таких игр организуется учителем другие игры или упражнения с одинаковой сложностью.

При обучении учащихся разного возраста и различного уровня физической подготовленности в пределах одного класса организация и проведение уроков физической культуры требуют от педагога тщательной подготовки. Физическая нагрузка регулируется в соответствии с программными нормативами.

В селах жизнь каждого ученика на виду. Поэтому легче найти индивидуальный подход к каждому ученику. Следовательно, учитель уделяет внимание каждому и учитывает интерес и уровень.

Таким образом, одной из важных проблем в малокомплектной школе является малая наполняемость класса. Учителя физкультуры испытывают трудности при организации занятий с малым количеством учеников в классах. Вследствие этого требуется поиск организационно-педагогических решений, предполагающих использование возможности обучать учеников в малочисленной школе по индивидуальным учебным траекториям.

Список литературы:

1. Коджаспирова Г.М., Коджаспиров А.Ю. Педагогический словарь: Для студ. высш. и сред. пед. учеб. заведений. - М.: Издательский центр «Академия», 2000. 176 с.

2. Крутецкий В.А. Психология обучения и воспитания школьников: книга для учителей и классных руководителей / В.А. Крутецкий. - М.: Просвещение, 1976. - 303 с

3. Унт И.Э. Индивидуализация и дифференциация обучения / И.Э. Унт. - М.: Просвещение, 1990. - 192 с. 